\title{
PLATÓN A ARISTOTELÉS O BOŽÍ VLÁDĚ V OBCI Možné zdroje ideje suverenity v řeckém politickém myšlení
}

\section{Jakub Jinek}

\section{Úvod}

Idea suverenity rozvíjená v politické teorii raného novověku získala ve 20. století nový - a nutno říci neočekávaný - impuls v příspěvku C. Schmitta, podle něhož nachází suverenita zdroj a současně nejzřejmější výraz v rozhodnutí o výjimečném stavu. ${ }^{1}$ Toto rozhodnutí suspenduje řád zákonných norem (či jeho část) a oproti obecnosti zákona se vyznačuje radikální kontingencí. ${ }^{2}$ Zcela zvláštní náboj dal Schmitt svému pojetí tím, že tuto souvislost suverenity a výjimky zapojil - a to bylo ve 20. století nepochybně ještě překvapivější - do theologického kontextu. „Všechny pregnantní pojmy moderní státovědy jsou sekularizovanými theologickými pojmy, “3 zní jeho známé diktum o souvislosti politiky s theologií, představující výchozí tezi jeho politické theologie, přičemž je to pojem Boží všemohoucnosti, jenž je předobrazem moderního státoprávního pojmu suverenity.

Dosah této teze je značný, ač na něj Schmitt sám, patrně záměrně, nikterak explicitně neupozorňuje. Moderní pojem suverenity je tímto způsobem de facto spojen se starou myšlenkovou tradicí, jež v božské monarchii viděla paradigma lidské vlády. Tato souvislost, z perspektivy

1 Toto je dvojí možný význam proslulé první věty Schmittova spisu Politická theologie: „Suverén je ten, kdo rozhoduje o výjimečném stavu (Souverän ist, wer über den Ausnahmezustand entscheidet).“ Čes. př̀ek1.: C. Schmitt, Politická theologie, přel. O. Vochoč, Praha 2012, str. 9. Její dvojznačnost nedovoluje přesně určit, zda možnost vyhlášení výjimečného stavu je pouze znakem suverénního statusu, anebo je jeho vyhlášení př́ímo tím aktem, jenž suverenitu plodí. Vzhledem k charakteru Schmittova spisovatelství lze soudit, že jde o dvojznačnost záměrnou a dobře promyšlenou, která má nechat ve hře současně obě možnosti.

2 Tamt., str. 9-13, 27.

3 Tamt., str. 31. 
moderního a současného myšlení nikterak samozřejmá, ${ }^{4}$ byla velmi dobře rozpoznána snad nejvýraznějším dobovým kritikem Schmittovy koncepce politické theologie. Erik Peterson, Schmittův dřívější přítel a kolega z bonnské university, avšak od vydání své kritiky jeho rozhodný oponent, ${ }^{5}$ založil svoje odmítnutí Schmittovy politické theologie - kterou nepovažoval za skutečnou vědeckou disciplínu, nýbrž spíše za zneužití theologie pro politické účely - na historicko-exegetické analýze antických, platónských a aristotelských, podle něj podobně problematických, koncepcí monarchické vlády.

V následujícím textu vycházíme $\mathrm{z}$ toho, že tato Petersonova intuice je do určité míry správná: je přiměřené zkoumat věc politické theologie, a tudíž také - předpokládáme-li systematickou spjatost obou problémů - věc suverenity na její prehistorii, na koncepcích autorů klasického řeckého politického myšlení. Tím ještě neříkáme, že jsou tyto koncepce správné či v jakémkoli smyslu autoritativní ve vztahu k modernímu chápání těchto otázek. Jde tu prozatím o metodické vyjasnění, že způsob, jakým o vztahu politiky a theologie uvažují klasičtí řečtí autoři, není irelevantní pro současné debaty o politické theologii, a že se dokonce $\mathrm{v}$ podstatných rysech shoduje s tím, jak tyto otázky znovuotevřel Schmitt. ${ }^{6}$ Tato afinita přitom, jak se domníváme, může podpořit legitimitu politické theologie jako takové.

4 Uvedená souvislost může být považována za kontroverzní těmi, kdo za klíčovou pro vznik politické theologie považují víru ve Zjevení, tj. v osobního Boha vyžadujícího poslušnost. Viz H. Meier, What is Political Theology, München 2006, str. 19-33. Zdá se nicméně, že ačkoli je pojem Boží všemohoucnosti (anebo pojem zázraku) oprávněně spojován až s abrahamovskými náboženstvími, o pozicích dřívějších pohanských autorů lze jako o politické theologii hovořit do té míry, nakolik se v nich objevuje filosoficky reflektovaný pojem boha a představa nutného podřízení jeho svrchované vládě, ač tato nutnost není vázána na představu osobní autority, ale moci neosobního principu (viz níže). Nepřímým dokladem toho, že náš výklad spojující Schmittovu tezi se starší tradicí se zcela nemíjí vlastními intencemi tohoto autora, budiž to, že pro Schmitta je rovněž deismus, v němž má pojem božství nepochybně neosobní charakter, formou politické theologie (viz C. Schmitt, Politická theologie, str. $31 \mathrm{nn}$ ).

$5 \quad \mathrm{~K}$ jejich rozporuplnému vztahu viz blíže B. Nichtweiss, Erik Peterson. Neue Sicht auf Leben und Werk, Freiburg i. Br. - Basel - Wien 1994, str. 725-762.

6 Naše interpretace tudíž vychází z přesvědčení, že uvedené Schmittovo politickotheologické diktum se nevyčerpává sociologickou či historickou tezí o sekularizaci původně theologických pojmů v moderní době (k tomuto výkladu viz H. Ottmann, Carl Schmitt, in: K. Ballerstrem - H. Ottmann, Politická filosofie 20. století, Praha 1993, str. 65-66), nýbrž je výrazem silné, systematicky nosné theologické teorie. 
Politická theologie může být v našem pojetí hledána všude tam, kde lze otázku: Kdo má vládnout?, jíž se vyznačuje klasická tradice politické filosofie, ${ }^{7}$ vposled převést na otázku Kdo je bůh? Ta se pro nauku o suverenitě stává relevantní v případě, kdy odpověd’ poukazuje k pojmu normativně chápané boží jedinosti, jež se pojí s představou svrchované vlády nad veškerenstvem. ${ }^{8}$

Přítomnost takového pojetí se budeme snažit prověřit u Platóna a Aristotela, přičemž svoje úsilí zaměříme nejprve negativně, ve snaze ukázat, že Petersonův výklad se - navzdory oné správné metodické intuici - zásadně mýlí v hodnocení politické theologie jako disciplíny postrádající veškerou theologickou legitimitu a sloužící výhradně instrumentálně politickým cílům. Ukážeme, že tento výklad má původ v hermeneuticky chybném chápání theologických stanovisek obou autorů, z něhož vyplývá i nesprávné pochopení vztahu politiky a theologie.

Právě na půdě hermeneutiky starých pozic tak lze provést přinejmenším částečnou revizi negativního hodnocení politické theologie jako celku. Pokud se nám podaří ukázat nesprávnost Petersonovy interpretace politické theologie u Platóna a Aristotela, ukáže se také nepřiměřenost jeho paušálního hodnocení této disciplíny. Tím naše tázání přesáhne pouhou exegetickou otázku po správnosti osmdesát let starého výkladu Platóna a Aristotela k otázce základnější, totiž zda může být politický problém vlády v obci, a příp. také problém suverenity, převeden, tak jak to vyplývá ze schmittovského dikta, na problematiku theologickou, nebo zda je jakýkoli takový pokus pouze politickým zneužitím theologie. ${ }^{9}$

7 Viz L. Strauss, O klasické politické filosofii, přel. V. Sochor, in: týž, Eseje o politické filosofii, I, Praha 2018, str. 69-70.

8 Nepochybně je takový pojem svrchovanosti pouze předchůdný moderní koncepci suverénního státu. Suverénní, tj. absolutní a trvalé (viz J. Bodin, Les six livres de la république, Paris 1576, I,8,122), je zde atributem vlády v obci (srv. formulaci Bodinovu na cit. místě: „dans la République, ..."), nikoli atributem státu vznikajícího tím, že se všichni vzdávají svých práv ve prospěch suveréna. Dějinně-filosoficky viděno se tedy námi sledovaný pojem svrchovanosti přibližuje pouze pojmu suverenity formulovanému J. Bodinem, nikoli pojmu suverénního státu u T. Hobbese.

9 To, že v této otázce nejde pouze o archivní záležitost, ukazuje současná debata o politické theologii, v níž se utkávají na jedné straně ti, podle nichž je jakékoli theologické a metafyzické založení politiky v rozporu se zásadami liberální demokracie a v jejím rámci mu fakticky již odzvonilo (M. Lilla, The Stillborn God: Religion, Politics, and the Modern West, New York 2007, str. 6, 302-316), a na druhé straně ti, kteří sledují schmittovskou intuici, podle níž se politická teorie nikdy nemůže zcela zbavit theologického či metafyzického založení (P. W. Kahn, Political Theology. 


\section{Kritika politické theologie}

Peterson se při své interpretaci Aristotela opírá o výklad Wernera Jaegera, jenž byl v době vydání Petersonovy knihy $(1935)^{10}$ považován za nezpochybnitelnou autoritu v oblasti aristotelských bádání. Jaeger klade silný důraz na theologickou nauku druhé poloviny XII. knihy Metafyziky, kterou chápe jako samostatné theologické pojednání, jehož vrchol vidí v proslulé poslední větě celé knihy citující homérskou Iliadu: „Ale věci nechtějí být spravovány špatně. Nedobrá vláda je mnohých - jen jeden vladařem budiž!“"11

Podle Jaegerova výkladu vyjadřuje tato věta nejzřetelnější odmítnutí platónského dualismu principů (jedna a neurčité dvojice). ${ }^{12}$ Proti tomuto dualismu se Aristotelés údajně přidržuje ,přísného monarchismu“ rozumu (nús), který myslí sám sebe. Božský vládce (archón) jakožto držitel jedinovlády (mia arché) zde spadá vjedno s posledním metafyzicko-theologickým principem (arché). ${ }^{13}$

Peterson tento Jaegerův výklad doplňuje v tom směru, že Aristotelův metafyzický „přísný monarchismus“ chápe jako odvozený od jeho politických představ: „,.. konečný obraz metafyzické jednoty světa je vždy již spoluurčován rozhodnutím pro jednu určitou podobu jednoty politické“. ${ }^{14}$ Peterson dokonce naznačuje, že Aristotelés zde mohl mít při psaní před očima Alexandra Makedonského, jehož údajně považoval za předobraz takovéhoto božského jedinovládce. ${ }^{15}$ Právě podřízením pojmu

Four New Chapters on the Concept of Sovereignty, New York 2011; K. D. Johnson, Theology, Political Theory, and Pluralism, Cambridge 2007, str. 140 nn.).

10 Citujeme dle pozdějšího vydání: E. Peterson, Der Monotheismus als politisches Problem. Ein Beitrag zur Geschichte der politischen Theologie im Imperium Romanum, in: týž, Theologische Traktate, München 1951.

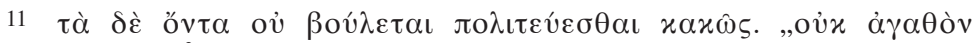

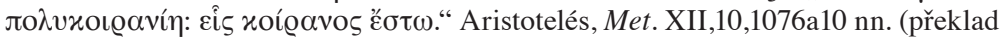
A. Kř́íz); viz Homér, Il. II,204 n.; srv. rovněž Aristotelés, Eth. Nic. II,5 závěr.

$12 \mathrm{~K}$ tomu viz práce citované níže, v pozn. 31.

13 Viz W. Jaeger, Aristoteles, Berlin 1923, str. 235-236.

14 E. Peterson, Der Monotheismus als politisches Problem, str. 52.

15 „Hat Aristoteles in der Formulierung seines monarchischen Ideales innerhalb der metaphysischen Ordnung die Vorentscheidung für die Prägung der hellenistischen Monarchie durch Alexander den Großen getroffen?“ Tamt., str. 108, pozn. 14. Srv. W. Jaeger, Aristoteles, str. 121. Peterson se zde patrně nechává inspirovat Hegelem, jehož vztah mezi Aristotelem a Alexandrem Makedonským silně fascinoval. 
božství politické představě o svrchovaném panovníkovi se Aristotelés stává v Petersonových očích předchůdcem politické theologie.

Svoji roli v tomto vývoji sehrál podle Petersona rovněž Platón. Jeho politická theologie však nebyla zaměřena monotheisticky, nýbrž na pozadí zmíněného metafyzického dualismu principů (jedna a neurčité dvojice) zavedla systematické rozlišení mezi božským panovníkem, jenž je držitelem vlády (arché), a podřízenými správními úřady vykonávajícími pouhou moc (dynamis). $\mathrm{V}$ tomto rozlišení se přitom připravuje dualistický výklad rozvinutý v pozdějším platonismu, kdy rozdíl mezi vládou a správou je viděn jako rozdíl mezi boží autoritou a upadlou donucující mocí: tím byla podle Petersona do politické theologie zavedena vlivná gnostická komponenta. Právě tuto politicko-theologickou strukturu si později osvojili pohanští filosofové v polemice proti křest'anům. Zdůraznili, že polytheismus je nutným vzorcem politiky, nebot' kromě vládnoucího nejvyššího boha je třeba vždy postulovat také nižší instance vykonávající správu a moc; bůh sám jakožto král nemůže spravovat zcela odlišné bytosti, jakými jsou lidé, stejně jako lidský panovník nemůže vládnout přímo nad stády zviŕrat. ${ }^{16}$

Raní křest'anští theologové se pak v odpovědi těmto pohanským filosofưm údajně naopak přidržovali přísného monotheismu, odpovídajícího Jaegerově obrazu Aristotelovy Metafyziky. Nižší božstva nemohou vykonávat samostatnou správu, nebot' jejich moc byla zrušena Bohem, stejně jako byla moc různorodých místních správ zrušena a nahrazena universalitou římského impéria. Tato universalita přitom pouze odráží Boží Prozřetelnost, která umožnila císaři Augustovi vybudovat světovou řîsi rušící a nahrazující pluralitu partikulárních místních vlád. Podle Petersona tak raní křest'ané užívali pojmu božské monarchie vposled stejně jako jejich pohanští protivníci, totiž polemicky a s politickou intencí, a provozovali tak politickou theologii v jím odmítaném smyslu. Aristotelské pojetí ,př́ísné monarchie“ se však podle něj ukázalo jako

Viz G. W. F. Hegel, Vorlesungen über die Geschichte der Philosophie, Stuttgart $1959^{3}$, II, str. 401.

16 Viz E. Peterson, Der Monotheismus als politisches Problem, str. 53-54, 73-75. Je pozoruhodné, že tato myšlenka, podle níž se král (podobně jako bůh) sám nemůže zabývat praktickými otázkami vlády nad ostatními bytostmi, se uplatnila rovněž ve zcela rozdílném historickém kontextu, totiž pro popis role francouzského krále v období Restaurace; srv. slavný Thiersův výrok „Le roi règne, mais il ne gouverne pas“ (Král vládne, ale nespravuje). (V publikované verzi „Le roi n’administre pas, ne gouverne pas, il règne“, viz L. A. Thiers, Du gouvernement par les chambres, in: Le National, 4. 2. 1830.) 
krajně nevhodné pro náležité uchopení křest’anského Boha, zejména pro rozlišení Božích osob. ${ }^{17}$ Byla to právě formulace ortodoxní trojiční nauky kappadockými otci a Augustinem, která od 4. století učinila přítrž jakémukoli paralelizování božského a lidského vládce. ${ }^{18}$

Petersonův výklad klasických autorů tedy nakonec vede $\mathrm{k}$ veskrze negativnímu soudu o politické theologii. Ta je bud' jakožto theologie nemožná, totiž pro svůj metafyzický dualismus nebo nediferencovaný monotheismus, anebo je kompromitována vedlejšími politickými motivy. V obou případech jde v Petersonových očích o neblahé dědictví řecké filosofie, at' už se rozvinulo $v$ pohanskou řeckou kritiku monotheismu, anebo vedlo k hellénizaci autentické židovské víry v jediného Boha v období prvních křest'anských apologetů. Jelikož Peterson při zkoumání kořenů tohoto řeckého dědictví odkazuje až k pozicím obou klasických autorů, Platóna a Aristotela, týká se onen negativní soud i jich. Platón s Aristotelem jsou - spolu s veškerou politickou theologií - křest'anskou trojiční vírou zcela vyvráceni, a to nejen jako pohanští autoři, jejichž pohled je přirozeně omezen tím, že jim nebyl přístupný obsah Zjevení, ale vůbec jakožto relevantní theologičtí autoři. To v důsledku znamená, že jejich theologická pozice nemůže být nijak relevantní pro politické myšlení. Dědictví klasické antiky je proto v bodě suverénní nadvlády jedince nad zákony bez užitku. Nejenže trojiční nauka osvobodila víru od politiky; zároveň s tím byla také osvobozena politika od falešného theologického založení, zejména od monarchické představy svrchovaného vladaře.

\section{Aristotelés}

Pro posouzení přměřenosti uvedené interpretace Aristotelovy politické theologie se musíme nejprve zaměřit na pojem „přísného monotheismu“ a položit si v jeho souvislosti dvě otázky: 1. zda je skutečně výstižnou charakteristikou aristotelské theologie; 2. zda je opravdu theologicky nepůvodní, tj. určovaný předchůdnou Aristotelovou politickou opcí pro (makedonskou) monarchii. Po zodpovězení obou dílčích otázek uvidíme, že Petersonův výklad je v obou bodech chybný.

Vzhledem k první otázce je třeba přiznat, že metafora božské jedinovlády není pro Aristotelovu theologicko-metafyzickou pozici zdaleka tak

17 Viz E. Peterson, Der Monotheismus als politisches Problem, str. 76.

18 Tamt., str. 102. 
určující, jak tvrdí W. Jaeger. Pohlédneme-li na argumentační strukturu XII. knihy Metafyziky, získáme poněkud diferencovanější obraz. Po první části knihy, která pojednává o viditelné podstatě (úsia), následují čtyřri kapitoly (Met. XII,6-9), jejichž tématem je skutečně věčná a nehybná podstata (1071b4-5). Těžiště této pasáže však nespočívá ve zkoumání nejvyšší podstaty samé, nýbrž spíše souvislosti této nehybné podstaty se světem pohybu, přesněji řečeno se sférou věčného pohybu a času (b6-7), tj. nebe. Nejde tudíž o popis vztahu božského a nebožského - budiž připomenuto, že nauka o nebi a o hvězdách představuje podstatnou, a možná dokonce tu nejvlastnější část aristotelské theologické spekulace (viz De caelo, I,10-II,1). Sotva tedy může být řeč o tom, že druhá část XII. knihy Metafyziky vyčleňuje prvního hybatele jako jediný předmět theologické vědy. ${ }^{19}$

Teprve v poslední, 10. kapitole XII. knihy se stává nehybný hybatel privilegovaným tématem, a to právě v politizující souvislosti monarchické vlády. Politická problematika vstupuje do hry vedle již zmiňovaného homérského citátu o samovládci také prostřednictvím dvou dalších obrazů: jedním je prríklad vojevůdce, který představuje cíl (telos) a řád (taxis) vojska; druhým je obraz domácnosti, jejíž svobodní členové sledují dobro celku, a to v protikladu k otrokům, kteří sledují pouze zájmy vlastní. To jsou velmi vhodné metafory pro předvedení boha jako garanta řádu, jejž ve světě působí, ovšem je otázka, zda je v této souvislosti oprávněné hovořit o monistické pozici. Vždyt' vojevůdce zohledňuje $d v a$ druhy dobra: kromě cíle, k němuž útvar vojska směřuje a jejž vojevůdce sám reprezentuje, je to také řád, jenž je vlastním, imanentním dobrem vojska samého (Met. XII,10,1075a11-13). Je tedy patrné, že celkový metafyzický obraz je v bodě dobra diferencován, a že lze tudíž jen s obtížemi hovořit o metafyzickém či theologickém monismu a monarchismu.

V př́ípadě metafory domácnosti se o posledním singulárním cíli nehovoří, a jediným dobrem, o němž je řeč, je ono imanentní dobro vlastní celku. Samozřejmě, že toto dobro má v řeči metafory svůj původ v hospodáři, nebot' je to patrně on, kdo je zodpovědný za to, že je domácnost „,nějak složena v řád“. ${ }^{20}$ Avšak jednak je tento řád diferencovaný (úch homoiós) a jednak přítomný obraz spíše zdůrazňuje roli, která přísluší

19 Srv. H. Flashar, Aristoteles, in: Die Philosophie der Antike, 3, Basel 2004, str. 335 .

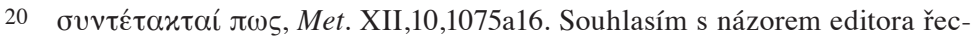
kého textu, že slova na řádcích a19-23, popisující příklad domácnosti, náleží jako

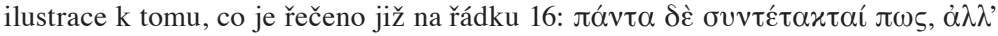

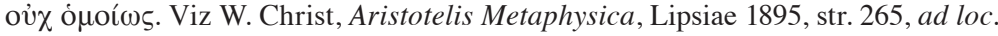


podřízeným prvkům, tedy svobodným ovládaným členům domácnosti, otrokům a zvirratům při sledování celkového dobra. Máme-li tuto metaforu číst ve světle nauky předcházejících kapitol 6-9, které rozlišovaly mezi dvěma úrovněmi božského, pohyblivou sférou hvězd a nehybným, transcendentním bohem, pak je patrně třeba tento rozdíl spojovat s rozdílem mezi svobodnými ovládanými členy domácnosti a hospodářem samým. Rozdílu mezi svobodnými a otroky (příp. zvíraty) by pak odpovídal analogický odstup mezi hvězdami jako božskými bytostmi a pomíjejícími entitami sublunárního světa. ${ }^{21}$

Pokud chceme toto vše nazývat přísným monotheismem (či monarchismem), pak jedině ve velmi specifickém aristotelském smyslu, který zdaleka přesahuje Jaegerovy interpretační záměry. Božský samovládce, jenž představuje jedinou příčinu a poslední, avšak nikoli jediné dobro, má v celkovém pojetí specifickou, přísně vymezenou úlohu. Vstupuje na scénu až poté, co již byly důkladně a, jak se zdálo, dostatečně probrány jiné - at' už božské či nebožské - entity, jako by se na něj Aristotelés, jak to vyjádřil P. Aubenque v souvislosti s paralelní theologickou pasáží z Fyziky, dodatečně rozpomenul jako na systematicky nutný poslední základ. ${ }^{22}$ Lze přitom ukázat, že tato situace až závěrečného, jaksi dodatečného zdůraznění principu zakládajícího celou stavbu, která již byla před tím provedena, není pouhou okolností, nýbrž promyšlenou metodou, která odráží těžko uchopitelný status nejvyšší podstaty mezi podstatami věčnými, ale pohyblivými, a tudíž i obtížný status próté filosofia $\mathrm{v}$ celkové struktuře Metafyziky. Tato figura se přitom opakuje v jiných Aristotelových centrálních dílech, typicky např. ve Fyzice VIII a Etice Nikomachově X. ${ }^{23}$

Pro nás je důležité, a tím se dostáváme k naší druhé otázce, že se s podobným argumentačním zvratem setkáváme rovněž v Aristotelově Politice. Ve III. knize nejprve Aristotelés podává výměr občana (III,1-5) a provádí vědecké rozdělení druhů zřízení (III,6-8). Následně

21 Viz P. Aubenque, Problém bytí u Aristotela, přel. M. Pokorný, Praha 2014, str. 367.

22 Důkaz boha předložený v VIII. knize Fyziky se omezuje - jak upozornil citovaný interpret - na fyzikální argumentaci z pohybu. Teprve poté, co Aristotelés dospěl k závěru důkazu prvního hybatele na podkladě této fyzikální argumentace, si „,náhle vzpomněl“" na transcendenci (tamt., str. 381).

$23 \mathrm{~K}$ podobě této figury v prvním uvedeném spisu viz předchozí pozn. V Etice dochází v 7. kapitole X. knihy k náhlému obratu pozornosti od praktického života ctností k životu rozjímavému, který je božský a vybízí člověka, aby překročil svou lidskou prrirozenost (Eth. Nic. X,7,1177b30 nn.). 
v 9. kapitole dospívá k ústřední otázce politické teorie Kdo má vládnout, jež se táže po oprávněnosti různých nároků na vládu. Zde jsou postupně relativizovány všechny obvyklé vládní nároky a s nimi spojená pojetí práva (diké) - nejprve právo oligarchů a demokratů, a poté i právo aristokratické (1283b28-35) -, přičemž Aristotelés dospívá k veskrze politické odpovědi na uvedenou otázku, tedy odpovědi založené na poznání toho, čím je polis jako taková. Jelikož je především společenstvím, a to „společenstvím dobrého života $\mathrm{v}$ domácnostech a rodech pro dokonalý a soběstačný život" (1280b33-35,40 n.) - což je definice odpovídající úvodnímu zjištění Politiky, že obec je svrchovaným zahrnujícím společenstvím (kyriotaté periechúsa koinónia, 1252a5-6) -, musí právo v obci dbát prospěchu celé obce a všech občanů. Výsledkem je pojetí práva, které je zahrnující a nikoho nevylučuje (1283b27-30, 1280a15-25), a taková má být i vláda v obci, tedy zákonná, ale současně lidová (tj. ve výsledku smîšená), jíž odpovídá zřízení politeie.

Avšak poté, co úvaha dospěla k přednosti zákonné lidové vlády, přichází na konci 13. kapitoly náhlý zvrat. Aristotelés zmiňuje, takříkajíc dodatečně, situaci, kdy jedna osoba v obci překonává ostatní občany ctností a schopností. Uzavírá, že takováto osoba nemůže být částí obce:

„Vždyt' takový člověk měl by být jako bůh mezi lidmi. Z toho je zjevno, že i zákonodárství se má vztahovat na lidi rovné i rodem i schopností a že pro tak vynikající lidi není zákona. Nebot' sami jsou zákonem.“24

To, že je taková situace považována za výjimku, vyplývá z dalšího myšlenkového postupu, v němž Aristotelés zmiňuje dvě možná řešení výskytu božské osoby v obci. První spočívá ve vyhnání božského člověka ze společenství pomocí ostrakismu. Aristotelés tuto možnost označuje platónsky jako „druhou plavbu“ a považuje ji za přijatelné řešení ve většině empirických případů. Druhá možnost je naopak vyhrazena nejlepšímu zřízení a je připuštěna - s určitým zdráháním - až na úplném konci kapitoly: v takovémto případě, říká Aristotelés, nezbývá nic jiného, než že se tato osoba stane ,věčným králem v obci““. ${ }^{25}$

24 Aristotelés, Pol. III,13,1284a10-14.

25 Tamt., 1284b25 nn. Správně bylo poukázáno na to, že toto zřízení, jež se odlišuje od zákonné monarchie známé šestičlenné klasifikace zřízení ze 7. kapitoly, je spíše paralelní k „sedmému“, nejlepšímu zřízení z platónského Politika (303b4), které se rovněž vymyká obvyklému klasifikačnímu schématu. Viz E. Schütrumpf, Aristoteles, Politik, II-III, Berlin 1991, str. 528. 
Závěr 13. kapitoly o božském člověku tak stojí v napětí k výše zmiňované relativizaci všech vládních nároků a $\mathrm{k}$ závěru předloženému na ústředním místě téže kapitoly, jenž vylučuje možnost vlády jedné či nemnoha osob z důvodu jejich převahy v ctnosti (1283b28-42). Takovéto napětí přitom není pouze výrazem obvyklého Aristotelova vnitřního dialogu; spíše se zdá, že to, co Aristotelés říká uprostřed 13. kapitoly, má v jistém smyslu konečnou platnost, a to, co říká na jejím konci, má tudíž formu dodatku, který je sice systematicky relevantní (k jeho významu viz níže), který však, jak naznačují Aristotelovy rozpaky, nepatří tak docela do vlastního politického pojednání. Struktura argumentace, kdy se autor nejprve přimlouval za zákonnou formu lidové vlády, aby pak na samý závěr připojil dodatek o výjimečném případu božského člověka, by pak zcela odpovídala výše popisovanému argumentačnímu postupu známému z Metafyziky, Fyziky i Etiky. ${ }^{26}$

Pro naše tázání z tohoto zjištění vyplývají dva poznatky, jeden s obecnou a druhý se specificky politickotheologickou platností: 1. Aristotelovo myšlení se vyznačuje strukturním rysem, který se opakovaně objevuje ve všech klíčových dílech a má povahu myšlení výjimky. Výjimka je chápána jako transcendentní a božská, je oproti normálnímu případu v jistém smyslu určující, přičemž však on sám od ní není jednoduše odvoditelný. Ve všech probíraných ústředních dílech je přitom rozlišitelná shodná dvojčlenná opozice normálního případu, jemuž je věnována největší pozornost (jednotlivé podstaty v metafyzice, pohybující se podstaty ve fyzice, mravní ctnosti v etice a pluralistická polis a její části v politice) a transcendentní výjimky (bůh-rozum, poslední hybatel, rozjímající filosof a svrchovaný král).

26 Závěr 13. kapitoly je přitom současně v napětí k tvrzení kapitol 15-16 stejné knihy, které - bez ohledu na jejich zjevně dialektický charakter - vylučují nadřazenost jakékoli osoby nad zákonem, což, jak se zdá, odpovídá také standardní Aristotelově pozici (1287b24-25). Po upřednostnění božské osoby tak následuje další myšlenkový zvrat směrem k přednosti zákona, který je poněkud zarážející a - vzhledem k námi indikované struktuře pojednání známé z Metafyziky, Fyziky a Etiky - jaksi nadbytečný. Je však možné, že zařazení kapitol 14-18, které sice pojednávají o království, avšak jsou zčásti vůči 13. kapitole v silném napětí, a navíc se svou metodou shodují s postupem IV. knihy (srv. již W. Jaeger, Aristoteles, str. 305, pozn. 1; odlišně W. L. Newman, The Politics of Aristotle, III, Oxford 1902, str. 256; srv. přesné znění Pol. IV,11,1296b10-12), není dílem Aristotela samého, ale spíše pozdějšího editora, jehož povrchní shoda tématu (království) mohla vést ke spojení dvou pasáží, které však patří do zcela odlišného myšlenkového kontextu. Pokud tomu tak je, lze 13. kapitolu a její závěrečnou theologickou pasáž považovat za závěr původního pojednání III. knihy; očekávána argumentační struktura by pak byla zachována. 
2. Pokud tato strukturně shodná transcendentní výjimka náleží ke všem vůdčím oborům a hraje $\mathrm{v}$ nich systematicky jasně určenou roli, může být sotva řeč o tom, že by do Aristotelovy theologie vstupovala zvenčí, z politické praxe. Reálně politický vliv nauky o jedinovládě je u Aristotela krajně nejistý - král stojící nad zákonem je pojímán jako výjimka, jíž je v politickém pojednání věnována v zásadě pouze dílčí pozornost; normálním př́ípadem politiky zůstává smíšená lidová vláda podle zákona. Přísný theologický monarchismus, který byl obtížně vykazatelný již v Metafyzice, nenachází ani v Aristotelově Politice, kde by podle Petersonovy teze měl mít vlastně původ, žádnou oporu. Politika zůstává u Aristotela samostatnou sférou a neovlivňuje oblast theologie.

To by nás však nemělo vést k závěru, že nezávislost platí i opačně, že tedy Aristotelova metafyzika či theologie nemá žádný vliv na jeho politické myšlení. Otázka, jakou roli hraje božská výjimka v oblasti politického života, zůstává naléhavou. Stojí-li totiž božská moc, která má vládnout i nad zákony, mimo vlastní politické pojednání, může její význam pro politiku vyplynout pouze $\mathrm{z}$ argumentace theologické. Taková argumentace, již nacházíme v uvedených, strukturně podobných pasážích Metafyziky, Fyziky či Etiky, přináší dvě dialekticky spjaté teze. Na jedné straně transcendence nejvyšší instance otevírá zcela novou úroveň zkoumání, na níž se ústředním pojmům platným na úrovni „,normální vědy“ (podstata, přirozenost, št'astný život) dostává zcela nového významu. V kontextu politickém se z běžného pojmu vlády, která je od I. knihy Politiky chápána jako vztah mezi vládcem a ovládaným, a je tudíž komplexním vztahem příkazů a jejich akceptace $v$ rámci nadřazené normy ${ }^{27}$ vyčleňuje pojem vlády zcela mimořádné intenzity, tedy vlády, která je jednostranná a není omezena žádnými ohledy. V tomto smyslu se zde - ač v náznaku a v zásadě pouze hypoteticky, nakolik je výskyt božského muže pouze předpokládán jako možný - rýsuje pochopení vlády jako svrchovanosti, tedy pojem suverenity.

Na druhé straně je ovšem odtažitost transcendentní výjimky ve všech případech kompenzována tím, že božská instance hraje roli vzoru, modelu k napodobení. ${ }^{28}$ Tak jako směřují věčné pohyblivé podstaty

27 Nadřazenou normou je, nejobecněji řečeno, bud’ fakt přirozenosti, jenž určuje určité osoby v rámci domácnosti k ovládání, anebo naopak umělý zákon určující vztahy podřízenosti a vlády mezi rovnými - občany.

28 Obecně je tento princip formulován v Met. IX,8,1050b28: „Ale také ty věci, jež jsou podrobeny změně, ... napodobují věci nepomíjející.“ 
k nápodobě podstaty nehybné, je rovněž člověk volán k napodobení božského. ${ }^{29}$ Pohlédneme-li z tohoto hlediska na božského muže, jenž je „odsouzen“"k trvalé vládě nad ostatními a představuje vzhledem k obyčejnému občanu jakousi odcizující výjimku, zjišt’ujeme, že právě díky této negativitě se může svobodným občanům stát vzorem a propůjčit jim nové životní směřování. Takováto myšlenka je skutečně naznačena na samý závěr III. knihy, kde se připomene dřívější poznatek, že v nejlepší obci se shoduje ctnost dobrého muže a ctnost občana, čímž se do hry dostane otázka výchovy (1288a38-39). Výsledkem „takřka téže“" (tauta schedon, b1) výchovy přitom může být jak ctnostný muž, tak rovněž politik a král; řeč je zde přitom o nejlepší obci, takže je zřejmé, že se zde myslí božský král absolutně nejlepšího zřízení: ten je tedy ve výchovném kontextu činěn srovnatelným - prostřednictvím dobrého muže - dokonce s běžným občanem.

Připomeňme na tomto místě obraz domácnosti užívaný v Metafyzice XII: Tak, jako se nebeská božstva vztahují k nejvyšší nehybné podstatě, vztahují se také svobodní členové domácnosti k svrchovanému vládci celku. V Politice je přitom naznačeno, že v tomto vztahu jde současně o otázku, nakolik se mohou ovládaní vládnoucímu přiblížit. ${ }^{30}$ Toto úsilí přitom zjevně určuje i vztah mezi nebem a nehybným hybatelem. Stará myšlenka nápodoby boha však pro lidi získává v aristotelské dvoustupňové theologii nový obsah: tak jako vzorem jednání běžného člověka není přímo jediný, transcendentní bůh (ač je nadále určující pro pojem božství), nýbrž spíše pluralita pohybujících se božstev (závislých na transcendentním bohu), které jsou bezprostředně pozorovatelné na obloze, a tudíž napodobitelné, podobně není ani pro běžného občana vzorem přímo nedosažitelný a svrchovaný božský král, nýbrž patrně - na základě paralelity jeho výchovy s výchovou dobrého člověka - plejáda rozumných a řádných mužů, jejichž vzácný, ale nikoli výjimečný výskyt v obci Aristotelova praktická filosofie předpokládá.

Takováto subtilní politická theologie samozřejmě neumožňuje politickou manipulaci směrem $\mathrm{k}$ monarchii. Jejím cílem je pouze přivést svobodné občany, kteří mají smysl pro celek a jsou schopni se reflexivně vztáhnout k pojmu božství, $\mathrm{k}$ úsilí o osobní zdokonalení v rámci tohoto celku. Chceme-li proto u Aristotela hovořit o politické theologii, pak jedině o politické theologii zákonné lidovlády-politeie.

29 Viz Aristotelés, Eth. Nic. X,7,1177b33.

30 Srv. týž, Pol. I,13,1259b26-36. 


\section{Platón}

Platónská politická theologie se zdála Petersonovi zvláště podežrelá svým dualismem, jehož vinou vůbec nemohla být skutečnou theologií. Není zde prostor probírat Platónovu nauku o principech, $\mathrm{k}$ jejímuž prozkoumání by bylo třeba zahrnout nepřímou tradici. ${ }^{31}$ Avšak již jen na základě systematicky ústředních dialogů, jakými jsou Filébos, Sofistés či Timaios, lze jistě souhlasit s tím, že Platónova metafyzika tíhne $\mathrm{k}$ pluralitě principů. Současně platí, že politické dialogy Politikos a Zákony zdůrazňující roli božské monarchie, jež se stává předobrazem lidského vládce pozvedajícího se nad ostatní lidi a nad zákony jakožto božská výjimka, ${ }^{32}$ pracují - s využitím shodného literárního obrazu, totiž vyprávění o Kronově božské vládě doplňované vládou jeho pomocníků démonů nad různými částmi země - s bipolární strukturou bůh - nižší božstva. ${ }^{33}$ Nutno tudíž přiznat, že Petersonova diagnóza, o niž se opírá i jeho kritika, je textově obhajitelná. Uvedená dvojčlenná theologická struktura navíc odpovídá Platónovým vlastním politickým preferencím, takže i pro něj může platit podezření z provozování politické theologie. Tyto preference jsou známy odjinud: z dialogu Ústava, jehož vlastní politický projekt spočívá ve svrchované vládě filosofa doplňované pomocníky. ${ }^{34} \mathrm{Na}$ rozdíl od Aristotela, kde theologie a politika zůstávají odděleny, tak spějí Platónovy theologické poznatky v prrímé linii k politickému uplatnění.

Pro zhodnocení legitimity platónské politické theologie je nicméně stejně jako u Aristotela rozhodující otázka, zda je ve spjatosti theologie a politiky primární ohled theologický, či prakticko-politický. I zde je

31 K tomu viz souhrnně G. Reale, Platón, přel. M. Cajthaml, Praha 2005, str. 204-216; H. J. Krämer, Plato and the Foundations of Metaphysics, New York 1990, str. 77-92; K. Gaiser, Platons ungeschriebene Lehre, Stuttgart 1963, str. 20-38.

32 V Politikovi je v souvislosti s ústředním pojmem ,přesnosti samé“ ( $\alpha$ ùò

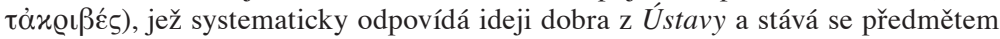
královského vědění, vyzdvižena osoba vládce stojícího nad zákony, který převyšuje ostatní lidi a jehož „zřízení “se od zřízení pouze zákonného odlišuje jako bůh od člověka (srv. Platón, Pol. 284d, 294a, 297a-b, 301e, 303b; srv. Resp. II,360c). - V Zákonech je rovněž připuštěna jedinovláda, a to ve (výjimečném) př́ípadě, kdy je vládnoucí osoba díky božské přízni ( $\theta \varepsilon i ́ \alpha \mu$ oî $\alpha)$ obdařena věděním a rozumem (Leg. IX,875b-d). K tomu je třeba přiřadit klíčové místo konce IV. knihy, podle něhož je vláda rozumu nápodobou vlády boha, přičemž rozum používá při rozdílení

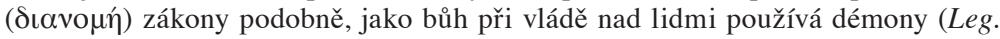
IV,713d-714a).

33 Srv. nicméně Platón, Leg. X,904a-c.

34 Viz Platón, Resp. III,414b; V,473d-474b. 
otázkou, zda se theologie nechává ovlivnit politickými představami svého autora, a je tudíž politickou theologií v Petersonově smyslu, anebo naopak politický model předpokládá a navazuje na genuinně theologický způsob myšlení.

Pro posouzení této otázky bude třeba nejprve ponechat stranou oba zmíněné politické dialogy a zaměřit se na tu část Platónova psaného díla, kde je vztah politiky a theologie traktován jako explicitní filosofický problém. Tak tomu není v Zákonech ani Politikovi, kde je tento vztah bud předpokládán jako daný (takový je zjevně úhel pohledu tří zbožných starců rozprávějících v Zákonech), anebo je skryt pod primární rovinou metafyzické spekulace (to je př́ípad Politika, v němž politická souvislost vyprávění o Kronově vládě vyvstane až na pozadí úvah o ,přesnosti samé"). ${ }^{35}$ Jinak je tomu v první tetralogii, a zejména pak v literárním páru Obrana Sókratova - Kritón, kde je souvislost politiky a theologie viděna z reálněpolitického hlediska občana konkrétní, athénské obce. Jde tudíž o perspektivu, která odpovídá typu tázání přítomnému rovněž v námi probírané části Aristotelovy Politiky. Sókratés zde hovoří o vládě, zákonu a bohu ze stanoviska běžného občana a teprve pozvolna dospívá k jejich propojení a vypracování theologicky rigorózního pojmu boha a jeho relevance pro otázky vlády v obci. Platí přitom, že ona prvotní perspektiva občanské theologie přechází v takovou filosofickou theologii, jež plně odpovídá tomu, co předpokládají oba výše uvedené politické dialogy.

Sókratovy theologické úvahy v Obraně se vyznačují zřetelným postupem od občanské theologie Sókrata - loajálního Athéňana k filosofické theologii suverénního filosofa. Sókratés začíná známým vyprávěním o orákulu v Delfách a jeho výroku o tom, že on sám je nejmoudřejším z lidí. V této fázi se Sókratés představuje jako pasivní objekt božského povolání. ${ }^{36}$ Již o něco později se však charakterizuje jako aktér uplatňující boží poslání dosti samostatně. ${ }^{37} \mathrm{~V}$ prostřední části díla (Apol. 28a-34b), která byla tradičně chápána jako odbočka, která však ve skutečnosti představuje samostatné theologické pojednání, se pak již

35 Viz výše, pozn. 32.

36 Již zde však v jeho hlavní motivaci, totiž dokázat nezpochybnitelnou pravdivost orákula (Apol.21e n.), nelze spatřovat pouze pasivitu, nýbrž rovněž jeho vlastní, aktivní teoretický zájem na pravdivosti boha.

37 Příslušné výroky, zdůrazňující Sókratův vlastní úsudek, vzbuzují jasné pochybnosti o jeho údajné pasivitě, která se tudíž jasně ukazuje jako sebestylizace: $\tau \hat{̣}$

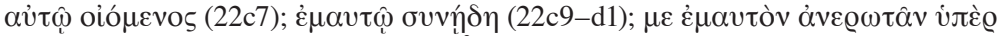

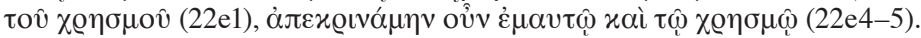


Sókratés vyhlašuje za partnera boha (a dokonce se přirovnává k synu boha Achilleovi), který sám (srv. egó v 28d4) interpretuje úkol, jejž mu bůh dal, a tím i svou pozici v řádu věcí (28d-e). ${ }^{38}$

Tato spjatost Sókratova zkoumání podstaty božství a současně jeho vlastního vztahu k němu je pro celý dialog typická. Proto se předmětem úvahy postupně stává samo Sókratovo já, na jehož charakter se zaměřuje pozornost. ${ }^{39}$ Otázka, co je Sókratés zač (srv. Apol. 23d1), není v dialogu přirozeně zodpovězena přímo. Jsou zde nicméně jisté náznaky odpovědi, které navozují jasnou souvislost s theologickou problematikou: 1. Sókratés je poslán bohem, 2. nalézá v sobě cosi božského a daimonského, 3 . vůbec se neobává smrti, 4. na základě svého vědění upřednostňuje duši, pravdu a moudrost před tělem a penězi. Jeho charakteristika vlastního já zde spadá vjedno s vlastnostmi božského, jež je nemateriální, řídí duši, je nesmrtelné a je spojeno s moudrostí. Těžko lze pochybovat o tom, že tyto vlastnosti ve svém celku charakterizují rozum (vov̂s), který je ve výše uvedených politických dialozích - ostatně jako v dalších dialozích označovaných jako pozdní - jménem boha samého. ${ }^{40} \mathrm{~V}$ Obraně nám tak Sókratés dává zahlédnout boha skrze svůj reflexivní postoj, takříkajíc na své vlastní osobě. Sókratés je theios, božský, a tedy také jeho postavení vůči ostatním je postavením boha mezi lidmi (29b3, 35a1; srv. 32b). ${ }^{41}$

A tak poté, co se občanská zbožnost proměnila v samostatnou disciplínu filosofické theologie, stává se tato theologie zpětně - reflexí na sdílené občanské náboženství a na postavení filosofa mezi ostatními - theologií politickou. Nejde zde přitom o onu tradiční theologia civilis, v níž je společný kult podřízen potřebám občanského společenství (a která by nejspíše odpovídala Petersonem odmítané disciplíně politické theologie),${ }^{42}$ nýbrž o politickou theologii, která se proti občanskému

38 Z tohoto hlediska je třeba pohlížet rovněž na všechny jeho výroky, které se

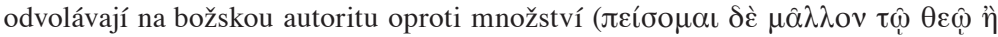

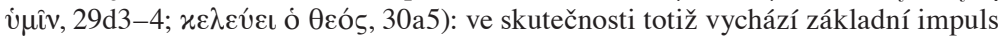
k odmítnutí úsudku množství ze sókratovského $\varepsilon \gamma \omega \omega ́$.

39 Tento charakter je - typicky platónsky (viz Crat. 432a-b; Resp. 438a-b; Soph.

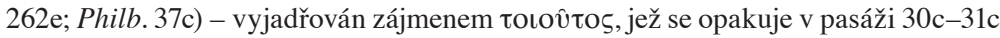
pětkrát ve shodném smyslu.

40 Srv. k tomu synopticky F. Karfík, Gott als Nous. Der Gottesbegriff Platons, in: D. Koch - I. Männlein-Robert - N. Weidtmann (vyd.), Platon und das Göttliche, Tübingen, 2010, str. 82-97.

41 Srv. Platón, Gorg. 473e-474a, 521d-e.

42 Varro, Antiquitates rerum divinarum, zl. 7-8, 11-12 (= Augustin, De civ. Dei, IV,31-32; VI,5-6). 
náboženství v mnohém revizionisticky obrací, a to právě redefinicí obou klíčových pojmů, božství i občanství. ${ }^{43}$ Nové pojetí boha již bylo naznačeno; revidované pojetí občanství lze pozorovat na Sókratově vlastním jednání - na tom minulém v obci i tom přítomném před soudem -, které znázorňuje skutečný úkol občana. Ten nespočívá ani tolik v zastávání konkrétního úřadu (32b1-2), jako spíše v plnění svých povinností, jež má v jiných dialozích jméno spravedlnosti, tj. „konání svého““ ${ }^{44}$ a jež Sókratés jako pravý politik nadaný v tomto převahou nad ostatními kontroluje nejen u sebe (kde může emfaticky konstatovat svoji stálost, 17b-d, 33a, 34b-35b) a u svých žáků (33a6-7), ale i zkoušením ostatních občanů a jejich přemlouváním (Apol. 22e, 23c, 28e-29a, 30a, 38a5; srv. Gorg. 521d7-10). Úkolem občanů (i v tom spočívá jejich „konání svého“) je pak zejména: tuto Sókratovu přednost uznat. ${ }^{45}$ Sókratova občanská theologie vztahu člověka a občana se tak připodobněním paradigmatického občana Sókrata $\mathrm{k}$ bohu proměňuje v suverénní monarchismus dokonalého občanství.

Rovněž dialog Kritón zdůrazňuje rozdíl mezi duší, resp. logem, a tělem a také zde stojí Sókratés na straně myšlení a duše vůči tělesnému, a tím i vůči většině lidí ${ }^{46}$ Opět je naznačeno, že tato konstelace jednoho proti mnohým má normativní důsledky, a tudíž i důsledky politické: tomu, kdo má vědění, náleží autorita, jíž se mají ostatní podřídit. ${ }^{47}$ Pro

43 V tomto smyslu by proto taková politická theologie spíše odpovídala Varronově theologia naturalis, ovšem s tím rozdílem, že zatímco podle Varrona nachází občanská theologie vedle té přirozené určité oprávnění, podle Platóna by jí vlastně měla být nahrazena.

44 Platón, Resp. $433 \mathrm{a} 8$ a passim.

45 Tento nárok je podle našeho přesvědčení přítomen v Sókratově smělém návrhu trestu, totiž být doživotně stravován na náklady obce v prytaneiu na Akropoli (Apol.36d-37a). Chápeme to jako přímou narážku na životní způsob strážců nejlepší obce, vyživovaných po celý život ostatními občany a žijícími právě na akropoli (Resp. IX,592b3; Leg. XII,946e-947e, 969c1-2). Že lze toto uznání v běžných podmínkách těžko očekávat, naznačuje výsledek Sókratova soudu, ale rovněž teoretické úvahy jinde (viz např. Resp. VI,487c nn.).

46 Sókratés dává přednost a řídí se logem, který je lepší a stabilnější (Crito, 46b-47a) a který kontrastuje s hédonistickými úvahami Kritóna a podobnými pocity většiny ostatních (43b4-9, 44b7,45e n.). Výraz duše se sice v dialogu přímo nevyskytuje, věcně je však tento pojem přítomen a vyjádřen slovy: „to, co se ... spravedlností stává lepším, nespravedlností však hyne“ (Crito, 47d4-5, srv. e6), která připomínají podobný popis z dialogu Faidón (Phd. 63c4-7).

47 Jde o v dialogu formulovaný princip rarity vědění (Crito, 47a-c), lépe známý z hlavního Platónova politického dialogu (Resp. II,379c, IV,428e, 431a-d). Podle tohoto principu je znalců od přirozenosti malý, a nikoli velký počet, což vede 
vyjádření tohoto podřízení se autoritě v oblasti umění týkajících se těla užívá Sókratés ${ }^{48}$ spojení ton nún prosechei (Crito, $\left.47 \mathrm{~b} 2\right)$, jež nese prima facie význam „věnovat pozornost“, ovšem současně se jím do diskuse uvádí - i když jen v náznaku - pojem rozumu (nús), tedy právě ten pojem, který podle indicií v Obraně vyjadřuje Sókratovu (božskou) autoritu. Když potom Sókratés v Kritónu přechází od otázek těla, jež je jednou složkou (ti) člověka (47c5-6), k „ostatním věcem“ (talla), z nichž vybírá - údajně z důvodů stručnosti (c9) - tu týkající se spravedlivého a nespravedlivého, ošklivého a krásného, dobrého a zlého, které jsou „nyní (nyn) předmětem naší úvahy“", tedy duši ${ }^{49}$ naznačuje tím, že mimo současný kontext (= nyn) by bylo možné hovořit ještě o ,jiných věcech“ v člověku, u nichž by platila stejná přednost jednoho vědoucího před mnohými nevědoucími. ${ }^{50} \mathrm{O}$ takových jiných věcech však Sókratés fakticky již hovořil, a to $v$ jedné $z$ výše zmiňovaných pasáží, kde uváděl, že poslouchá „ze svých věcí“ (tón emón) pouze lepší logos (Crito, 46b4). ${ }^{51}$ Je-li však řeč o lepším logu oproti horšímu, je ve hře myšlení, a onou hledanou částí je patrně rozum, nús. ${ }^{52}$

Rozum je zde onou skrytou autoritou, ${ }^{53}$ kterou se řídí na jedné straně Sókratés sám a která je - prostřednictvím dílčích vědění specialistů anebo prostřednictvím Sókratova myšlení - rovněž poslední autoritou pro ostatní, kteří mají dbát na to, co říká jeden vědoucí. Sókratovi tak i v Kritónu náleží, a to na základě stejné mohutnosti jako v Obraně, ona

k poznatku,že je nutné poslouchat jednoho odborníka oproti názoru mnohých (Crito, 47b9-c3).

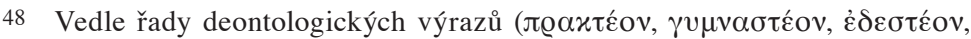

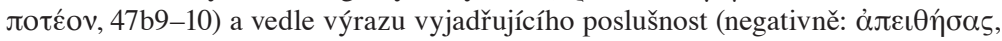
47c1).

49 Viz výše pozn. 46.

50 O takové věci by podle uvedených formulací platilo, že je něčím, co při zkoumání jednotlivých aspektů člověka náleží vůči tělu do skupiny „,to ostatní“ ( $\tau \hat{\alpha} \lambda \lambda \alpha)$. Tam sice patří spolu s duší, ta však na rozdíl od ní samé byla z této skupiny vyčleněna jako to, čehož projednání je snazší.

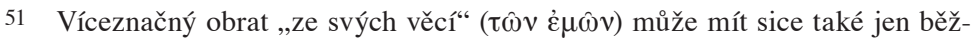
ný význam poukazující na přátele nebo majetek (takto R. Weiss, Socrates Dissatisfied. An Analysis of Plato's Crito, New York - Oxford 1998, str. 58), může však také - jako jinde u Platóna (Resp. IV,443c-d; Alk. I,129a-133d) - označovat části lidské osoby. Sókratés zde pátrá po spolehlivé autoritě ve své duši a nachází ji v tom psychickém aspektu, jemuž náleží „,lepší logos“. Srv. též Crito, 50a9.

52 Srv. F. L. Lisi, Einheit und Vielheit des platonischen Nomosbegriffes, Königstein 1985, str. 76.

53 Srv. níže, pozn. 55. 
dvojjediná úloha poslouchajícího a toho, jehož je radno poslouchat. První aspekt je přitom opět spojen se Sókratovou občanskou rolí: Sókratova poslušnost rozumu spadá ve svých důsledcích vjedno s poslušností athénským zákonům. Pokud se podíváme na tyto důsledky, zjišt’ujeme, že jeho poslušnost se váže na skutečnosti týkající se jeho narození, péče o něj v útlém věku, jeho výchovy a pobytu v Athénách,${ }^{54}$ tedy že platí zejména po stránce tělesné neboli, jak výslovně uvádí, co do činu (ergó, 51e3; srv. ergó all'ú logó, 52d5). Avšak motivace této poslušnosti je, jak známo, zcela jiná. Na proslulém místě dialogu Faidón Sókratés v situaci, která z hlediska dramaturgie dialogu silně připomíná naše místo z Kritó$n a$, uvádí, že se zákonu podřizuje a fyzicky sedí ve vězení nikoli z rozhodnutí těla, nýbrž rozumu, nús (Phd.98d-99b); ${ }^{55} \mathrm{v}$ našem dialogu je na místě tohoto důvodu jmenován (v singuláru) bůh, theos $(C r i t o, 54 \mathrm{e} 2)$.

K této složité konstelaci, která odpovídá - stejně jako v Obraně - rozdílu mezi jedním božským a rozumným vládcem, který je sám poslouchajícím i přikazujícím, a mnohými ovládanými, přistupuje nyní v Kritónu třetí člen - zákon (nomos). Jak bylo v literatuře již upozorněno, athénské zákony hovořící v Kritónu silně připomínají entity platónské metafyziky: ${ }^{.6}$ jsou objektivní normou, jsou faktické, nikoli hypotetické, mají věčný původ a jsou dostatečným předmětem poznání. ${ }^{57} \mathrm{~V}$ uvedené konstelaci se tedy zákon podobá jednoznačně složce duševní a rozumové, a tedy Sókratovi. Tak jako se v Apologii odhaluje spřízněnost Sókrata s bohem, jde v Kritónu o afinitu filosofa se zákonem; pojítkem zákona a božství je v našem dialogickém páru společný kontrast s (pouze) lidským (Apol. 29d2-4; Crito, 54b8 n.). ${ }^{58}$ Avšak v Kritónu, podobně jako

54 Jak zdůrazňuje druhý (Crito, 50e-51c) a třetí (Crito, 51c-53a) ,,argument zákonů“.

55 Je přitom nápadné, že na exponovaném místě dialogu Faidón je rozum vyjádřen nikoli výrazem běžně chápaným jako protiklad ع̌o $\gamma \omega$, tedy $\lambda$ ó $\gamma \omega$, nýbrž výrazem vô (Phd. 99a8). Lze tak říci, že dramaturgicky následující dialog Faidón čtenáři poskytuje jasné interpretační vodítko, jak chápat $\lambda$ ó $0 \varsigma$, o němž mluví Sókratés v Kritónu (46b5-6), totiž jako voûs.

56 Viz H. Flashar, Überlegungen zum platonischen Kriton, in: H.-C. Günther - A. Rengakos (vyd.), Beiträge zur antiken Philosophie. Festschrift für Wolfgang Kullmann, Stuttgart 1997, str. 58.

57 Viz Platón, Crito, 51c-52d, 54c.

58 Systematická souvislost obou protikladů - mezi člověkem a bohem na jedné straně a mezi člověkem a zákonem na straně druhé -, jež jsou k sobě korelativně vztaženy, spočívá v tom, že u Platóna zaujímá zákon roli ,zástupce“ boha. Podrobné zpracování této problematiky nacházíme na ústředním místě IV. knihy Zákonů, kde 
v Obraně, je pojem rozumu rovněž přímo spjat s pojmem božství, a to jednak již zmiňovaným určením boha jako poslední autority ve věci rozhodnutí, zda uprchnout, či zůstat ve vězení (Crito, 54e2), jednak výslovnou paralelizací úsudku „bohů a lidí majících rozum“.59

Spřízněnost božského rozumu, zákona a filosofa, jež je hlavním obsahem politickotheologické nauky dialogů Politikos a Zákony, se v našem dialogickém páru uplatňuje rovněž v tom, že Sókratés disponuje pravdivým logem o athénských i cizích zákonech (Crito, 52d). Znalost cizích zákonů je přitom předpokladem zákonodárné činnosti, přičemž připomeňme, že je to právě živel řeči (logó), v němž se Sókratés v Ústavě (a Athéňan v Zákonech) stává zákonodárcem. ${ }^{60} \mathrm{~V}$ Obraně je téma zákonodárství zpřítomňováno otázkou po možnosti vylepšování daných zákonů (Apol. 37a7) a v Kritónu prostřednictvím výzvy zákonů adresované Sókratovi, aby je ,„p̌remluvil“", což v dobové terminologii znamená: navrhl jejich změnu (Crito, 51b-c).

Hlavní Platónův zákonodárný dialog Zákony je přitom jasným dramaturgickým pokračováním rozhovoru v Kritónu. ${ }^{61}$ Athénský cizinec odpovídá typu suverénního filosofa z první tetralogie, jehož nyní Zákony ukazují při zákonodárné činnosti zaměřené na existující krétské obce. Místo mu připravuje v celé první tetralogii skrytě přítomná otázka po Sókratově nástupnictví (viz např. Crito, $39 \mathrm{c}-\mathrm{d}$ ) spojená s myšlenkou, že nástupce nebude mít již tak těsný vztah k athénským zákonům jako

je zákon úzce asociován s bohem a naopak kontrastován s vládou člověka. Viz Platón, Leg. IV,713e-716a; srv. I,645b; IV,711d-712a, XII,951b; Resp. VI,499a-c.

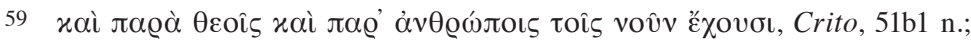
srv. $47 \mathrm{~b} 1 \mathrm{n}$.

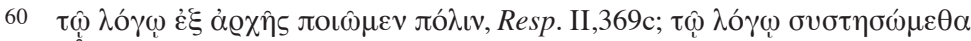

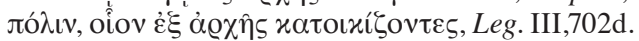

61 Mnohé symbolické náznaky hovoří pro možné pokračování filosofova působení na Krétě, ač k takovému pokračování, z důvodů emfaticky předložených v Kritónu, nebude moci být povolán Sókratés sám. Dialog Kritón končí slovem „bůh“, jímž naopak Zákony začínají. Lod', která připlula z Délu, aby přinesla Sókratovi smrt (Crito, 43c9), je stejnou lodí, na níž plul na Krétu hrdina Théseus. Podobně jako Théseus, jehož jeho otec Aigeos zkoušel přemluvit, aby neplul na Krétu, chce-li si zachovat život, zdráhá se rovněž Sókratés, tento nový Théseus, naslouchat Kritónovi a ještě během svého života uprchnout (Crito, 52e; srv. Apol. 37c). Co mělo oběma - Théseovi a Sókratovi - podle všeobecného přesvědčení přinést smrt, jim naopak propůjčilo nesmrtelnost. Právě tento skrytý odkaz k problému nesmrtelnosti - v první tetralogii zcela dominantnímu - otevírá otázku Sókratova nástupnictví - viz dále náš výklad v hlavním textu. Nesprávně naopak L. Strauss, The Argument and the Action of Plato's Laws, Chicago - London 1975, str. 2. 
Sókratés, protože bude v jistém smyslu v Athénách cizincem. Cizinectví je přitom Řeky vnímáno jako předpoklad pro to stát se úspěšným zákonodárcem. Sókratés poslouchal athénské zákony a podstoupil na jejich př́kaz fyzickou smrt, ale jeho logos či nús nadále působí v jeho žácích, kterým je dovoleno odejít z Athén, třeba právě na ostrov Kréta, který se právě podle toho, co uvádí dialog Kritón, zdá být nejvhodnějším místem pro odchod filosofa z rodné obce (Crito, 53a-54a). „Kolonie liebt der Geist" (duch miluje kolonii), pěje novodobý theolog a znalec řecké filosofie, ${ }^{62}$ a to ve shodě s Platónem, podle jehož Politika je rovněž kolonie nakonec tou nejvhodnější metaforou pro působení nejvyššího metafyzického principu ve světě. ${ }^{63}$

Božská rozumná instance, jež je rovněž potenciálně zákonodárná, tak představuje překvapivou pointu sókratovské občanské theologie v Obraně i Kritónu. Sókratův občanský postoj nechává božský nús ponenáhlu vystoupit před zrakem čtenáře a umožňuje mu pochopit, že je to právě božská výjimka rozumného filosofa, které má náležet vláda nad obcí. Pro náš výklad je ovšem neméně než tato pointa důležitá „,nepolitickopolitická" komponenta občanské theologie. Sókratova ochota podstoupit smrt z rukou Athéňanů podle litery positivního athénského zákona ukazuje, že jeho občanská theologie se nemusí nutně stát v reálné politice dominantní. Sókratés sám se, jak zdůrazňuje, od běžné politiky a od zákonodárné iniciativy distancoval. Znamená to, že platónská politické theologie není nikterak nutně určena představou kýžené politické formy.

Má-li se však tato theologie stát politikou, a s takovou možností se již v obou zmiňovaných ,pozdních“ dialozích pevně počítá, v takovém př́padě již sleduje svá vlastní pravidla, pravidla nús a logos. To je perspektiva dialogu Politikos: božská pořádající vláda rozumu není vázána zprostředkující mocí zákonů a nižších úřadů (v theologické terminologii: vláda boha není vázána na pomoc démonů). Pomoc zákona potřebuje pouze jakožto správa existující v konkrétních dějinných podmínkách - a to je zase hlavní perspektiva Zákonů -, ale nikoli jakožto božská moc zákonodárná. Bůh je v první řadě modelem zákonodárce - zákonodárství je základní podobou platónské politické theologie. V tomto smyslu je Platónova politická theologie, jež je v první řadě theologií, vhodným polem pro formulaci myšlenky suverenity.

62 F. Hölderlin, Brot und Sein, in: týž, Sämtliche Werke, I, Stuttgart 1944, str. 381 .

63 Platón, Polit. 284e7-8. 


\section{Závěr}

Idea suverenity je v klasickém řeckém politickém myšlení přítomna, pokud ji chápeme spolu se Schmittem jako projev politické theologie. Neplatí, že politická theologie je možná pouze v rámci abrahamovských náboženství. Již v pohanské řecké tradici, konkrétně u Platóna, se rýsuje jako dominantní otázka po identitě boha, která pak určuje odpověd' na otázku po vládě mezi lidmi. U Aristotela je tato myšlenka zastoupena v jiném, pro konstituci pozdější teorie suverenity spíše vedlejším smyslu. Bůh a božský vládce je teoretickou výjimkou, která na rozdíl od platónského výjimečného muže nemá reálný předobraz (u Platóna by jím byl dialektický filosof sókratovsko-platónského typu, tedy např. Platón sám). Zůstává tak pouze hypotetetickou možností otevřenou principiálně libovolné osobě splňující abstraktní kritéria božství, a je tak božstvím bez konkrétní identity. To sice na jedné straně umožňuje vybavit ji absolutní mocí, na druhé straně se však fakticky opouští skutečný nárok na aktuální vládu. Posun ve znění hlavní otázky: kdo vs. někdo, posun mezi realitou božské vlády a její pouhou hypotézou vyznačuje hlavní rozdíl mezi dvěma antickými autory a zároveň mezi dvěma politickými tradicemi.

V souhrnném pohledu na tyto dvě tradice a jejich zakladatele nepostrádá náš výsledek ve vztahu k původní Petersonově kritice takřka komické rysy. Situace je totiž přesně opačná, než Peterson tvrdil. Je to Platón, kdo je př́iznivcem politické theologie ve smyslu monarchismu a paradigmatismu boží vlády; je však primárně motivován theologickou otázkou Kdo je buih?, a tedy podezření z theologické nesolidnosti je třeba odložit jako liché. Naopak Aristotelés používá theologickou terminologii v politickém kontextu pouze jako krajní horizont diskuse o zřízení, která je však fundamentálně určena jeho pojetím participativního občanství, práva a zákonnosti. Peterson je zde zřejmě sveden svou, podle Schmittova pozdějšího vyjádření silně stranickou, konkrétně konfesně-politickou agendou (zahrnující programové potírání aristotelské filosofie a snahu o očištění křest’anské tradice od nánosů pohanského řectví) a zároveň agendou občansko-politickou (jejímž cílem je „,demokratizace“). V tomto druhém bodě se nevědomky stává přívržencem Aristotelovy politické theologie, totiž politické theologie demokracie. ${ }^{64}$

64 Podpořeno z projektu GA ČR č. 16-20390S (Eroze suverenity a post-nacionální vládnutí v době krize). Autor děkuje oběma anonymním recenzentům za podnětné připomínky. 


\section{ZUSAMMENFASSUNG}

Der vorliegende Beitrag diskutiert die Frage, ob der Begriff einer politischen Theologie als Grundlage für die Idee der Souveränität bei den klassischen griechischen Autoren Platon und Aristoteles zu finden ist. Im Gegensatz zu einigen kritischen Stimmen gegenüber einer politischen Theologie, die in ihr einen Versuch sehen, die Theologie für praktisch-politische Zwecke zu missbrauchen auf der einen Seite und im Gegensatz zu denen, die bezweifeln, dass in der klassischen Antike eine echte politische Theologie zu finden ist auf der anderen Seite, zeigt unsere Interpretation zweierlei: erstens entwickeln beide, Platon und Aristoteles, klare - wenn auch voneinander verschiedene - politisch-theologische Positionen und zweitens hat bei beiden die theologische Spekulation Vorrang vor allen praktisch-politischen Erwägungen. Bezüglich des Unterschieds zwischen den beiden Autoren zeigt sich, dass nur Platon als Vorreiter der modernen Idee der Souveränität angesehen werden kann.

\section{SUMMARY}

The article discusses the notion of political theology as a basis for the idea of sovereignty in Plato and Aristotle. Contrary to those critical voices which view political theology as an attempt to misuse theology for practical-political purposes on the one hand, and those who question the very presence of political theology in classical Antiquity on the other, our interpretation shows that, first, both Plato and Aristotle do develop clear, though mutually distinct, political-theological positions and second, that in both cases, theological speculation has priority over considerations of practical policy. Concerning the difference between the two authors, however, it turns out that Plato is the only one for whom political theology is constitutive of what could be seen as a precursor of the modern idea of sovereignty. 